\title{
CONSTRUCTION INDUSTRY SURVEY AND STUDY THE SUSTAINABLE PUBLIC PROCUREMENT
}

\author{
Deepali D Kadam ${ }^{1}$, R.V.Devalkar ${ }^{2}$ \\ ${ }^{1}$ M.E Construction Mgt. Student, Civil Engineering, N.D.M.V.P.S'S.K.B.T.C.O.E Nasik, Maharashtra, India \\ ${ }^{2}$ Assistant Professor, Civil Engineering, N.D.M.V.P.S'S.K.B.T.C.O.E Nasik, Maharashtra, India
}

\begin{abstract}
In India construction industry is improving the social, economic and environmental indicators of sustainability. We aware about that the endangering the future of forth coming generations due to leaving depleted resources or no resources. As far as concerns with growing sustainability have led the construction industry to adopt various policies for reducing the impacts caused by construction activities. The aim of this study are to find out the awareness and extent to which sustainable procurement practices in Nasik city is carried in construction industry. To find out what construction industry thinks on sustainable procurement. In this qualitative methods is used which are based on descriptive scales. The entire analysis is carried out by statistical analysis method and relative important index, and then by the score computed ranking is be done. There are many barriers that came forward through the survey which needs to be worked out by the industry so that such an important issue can be solved. Lack of sustainable performance in the project is because of issue is not being brought into the focus and even the industry is not well known about the benefits of the green products. From the overall survey carried it can be concluded that the entire topic needs to be focused and for the same experts opinion and views for the same should be taken into consideration, and also use of sustainable materials should be increased and social awareness should be created.
\end{abstract}

Keywords: Sustainable Public Procurement, Relative Important Index, Sustainable Development

\section{INTRODUCTION}

Now a day's industries are more concentrating and involved in designing and implementing sustainable procurement policies and keep attention on how environmental issues and issues relating to other aspects of the sustainable development pillars can be integrated in the procurement process activities. In India construction industry is improving the social, economic and environmental indicators of sustainability. We are aware about that the endangering the future of forth coming generations due to leaving depleted resources or no resources. Therefore construction industry in India an active effort is extremely essential for sustainable development and leave resources for the future generation to satisfy their needs. In recent years, the construction industry has also adopted green public procurement in which a process whereby contracting authorities aim is to procure services and products that meet environmental requirements. In some cases the green public procurement has stretched to sustainable public procurement in which involves the incorporation of both environmental and social aspects in the procurement of services and products. Sustainability in the construction industry is a significant challenge. This challenge is due to the requirement of high levels of support among project stakeholders on the one hand and coordination between project planning and implementation on the other hand. Traditional procurement has play complete attention upon value for money considerations. Sustainable procurement the aim and challenge is to integrate environmental and social considerations into the procurement process with the reducing adverse impacts upon health, social conditions and the environment by saving valuable costs for public sector organizations and the community at large extent. Sustainable procurement is a key part of an overall push for sustainable development by governments.

\section{METHODOLOGY}

\subsection{Analysis Method}

In this Qualitative methods will be used which are based on descriptive scales, and are used for describing the likelihood and impact. The aim of this present work is to find out the important factors affecting on performance of procurement based on Principle of Sustainability i.e technical, social, economic and environmental aspect. The questionnaire interview was carried out among 53 construction companies which are located in the Nasik region of Maharashtra (India). The 53 interviews took place over a 3 month period between August to October 2015 and each lasted approximately half hours. The questionnaire was carried through face-to-face interviews and it consisted of 56 closed ended questions. The interviews reflects the opinion of experts from 53 firms, it is believed that they can give an idea about the important factors affecting on performance of procurement based on Principle of Sustainability in the Nasik region, Maharashtra (India) construction industry. Descriptive survey is preferred because it gives quick answers to the questions and does not consume much time of the respondents. The entire analysis will be carried out by Relative Important Index, and then by the score computed ranking will be done. 


\subsection{Relative Important Index}

Relative important index is a regression-based index which summarizes the magnitude of socio-economic status.RII is useful because it takes into account the size of the population and the relative disadvantage experienced by different groups. By using this method we can rank a particular aspect by means of the score computed which depends upon the total responses received in terms of scale by the highest scale value multiplied by number of responses.

\section{$\mathrm{RII}=\sum \mathrm{W} / \mathrm{A} \times \mathrm{N}$}

Where,

$\mathrm{W}=$ Weighting given to each factor by the respondents and ranges from 1 to 5

Where ' 1 ' is no significant,

' 5 ' extremely significant

$\mathrm{A}=$ Highest weight

$\mathrm{N}=$ Total no. of respondents

\section{RESULT}

Overall 53 questionnaires was prepared and sent to various companies through mails, and personal meetings.

Table 1. Show the questionnaire response rate

\begin{tabular}{|l|l|l|l|l|}
\hline $\begin{array}{l}\text { Question- } \\
\text { naire } \\
\text { Sent }\end{array}$ & $\begin{array}{l}\text { Response } \\
\text { Received }\end{array}$ & Rejected & Incomplete & Total \\
\hline 53 & 27 & 10 & 16 & 53 \\
\hline
\end{tabular}

Questionnaire Response Rate $=51 \%$

Table 2. Showing technical aspects importance as per the respondent

\begin{tabular}{|l|l|l|l|}
\hline Sr.No & Technical Aspects & RII & Rank \\
\hline 1 & $\begin{array}{l}\text { Building Byelaws, } \\
\text { \&regulations }\end{array}$ & 0.874074 & 1 \\
\hline 2 & Project Type & 0.755556 & 5 \\
\hline 3 & Project Team Size & 0.681481 & 7 \\
\hline 4 & Procurement Methods & 0.785185 & 3 \\
\hline 5 & Project Completion Time & 0.696296 & 6 \\
\hline 6 & $\begin{array}{l}\text { Early Completion of } \\
\text { Project }\end{array}$ & 0.585185 & 9 \\
\hline 7 & Project work flexibility & 0.474074 & 10 \\
\hline 8 & Construction Risk & 0.837037 & 2 \\
\hline 9 & Pre Contract Planning & 0.777778 & 4 \\
\hline 10 & Cost overrun & 0.688889 & 8 \\
\hline
\end{tabular}

Table 3. Showing economic aspects as per the respondents

\begin{tabular}{|l|l|l|l|}
\hline Sr.No & Economic Aspect & RII & Rank \\
\hline 1 & Local available material & 0.822222 & 3 \\
\hline 2 & Procured material cost & 0.8 & 4 \\
\hline 3 & Reuse of materials & 0.733333 & 7 \\
\hline 4 & $\begin{array}{l}\text { Material cost and its } \\
\text { reduction }\end{array}$ & 7 \\
\hline 5 & Quality of material & 0.733333 & \\
\hline 6 & Budget problems & 0.703704 & 8 \\
\hline 7 & Shortage of suppliers & 0.622222 & 9 \\
\hline
\end{tabular}

\begin{tabular}{|l|l|l|l|}
\hline 8 & Operational cost & 0.748148 & 6 \\
\hline 9 & Greater efficiency & 0.844444 & 2 \\
\hline 10 & New market opportunities & 0.777778 & 5 \\
\hline
\end{tabular}

Table 4. Showing environmental aspects as per the respondents

\begin{tabular}{|l|l|l|l|}
\hline Sr.No & Environmental aspects & RII & Rank \\
\hline 1 & Ecofriendly materials & 0.725926 & 6 \\
\hline 2 & $\begin{array}{l}\text { Protect the natural } \\
\text { environment }\end{array}$ & 0.814815 & 3 \\
\hline 3 & $\begin{array}{l}\text { Minimum resource } \\
\text { consumption }\end{array}$ & 0.785185 & 4 \\
\hline 4 & $\begin{array}{l}\text { Use of Lower hazardous } \\
\text { material }\end{array}$ & 0.881481 & 1 \\
\hline 5 & Use of Green Products of & 0.6 & 9 \\
\hline 6 & $\begin{array}{l}\text { Optimum use of } \\
\text { resources }\end{array}$ & 0.659259 & 8 \\
\hline 7 & $\begin{array}{l}\text { Effective disposal } \\
\text { construction waste }\end{array}$ & 0.518519 & 10 \\
\hline 8 & Climate change & 0.777778 & 5 \\
\hline 9 & $\begin{array}{l}\text { Emissions, effluents and } \\
\text { waste }\end{array}$ & 0.696296 & 7 \\
\hline 10 & Use of water & & \\
\hline
\end{tabular}

Table 5. Showing social aspects as per the respondents

\begin{tabular}{|c|c|c|c|}
\hline Sr.No & Social Aspects & RII & Rank \\
\hline 1 & $\begin{array}{l}\text { Management internal } \\
\text { issues }\end{array}$ & 0.614815 & 9 \\
\hline 2 & Labor management issues & 0.674074 & 7 \\
\hline 3 & Past experience & 0.755556 & 4 \\
\hline 4 & Past performance & 0.755556 & 4 \\
\hline 5 & $\begin{array}{l}\text { Customer health and } \\
\text { safety }\end{array}$ & 0.725926 & 5 \\
\hline 6 & $\begin{array}{l}\text { Client's needs and its } \\
\text { satisfaction }\end{array}$ & 0.874074 & 2 \\
\hline 7 & $\begin{array}{l}\text { Social awareness about } \\
\text { sustainable procurement } \\
\text { of construction materials }\end{array}$ & 0.659259 & 8 \\
\hline 8 & $\begin{array}{l}\text { ethical and responsible } \\
\text { treatment of labor }\end{array}$ & 0.77037 & 3 \\
\hline 9 & $\begin{array}{l}\text { Maximum use of local } \\
\text { suppliers }\end{array}$ & 0.681481 & 6 \\
\hline 10 & $\begin{array}{l}\text { Maintaining } \\
\text { relations }\end{array}$ & 0.903704 & 1 \\
\hline
\end{tabular}

Table 6. Showing probable reasons due to which sustainable procurement is not being practiced at high rate

\begin{tabular}{|l|l|l|l|}
\hline Sr.No & Probable reasons & RII & Rank \\
\hline 1 & $\begin{array}{l}\text { The lack of Building } \\
\text { Codes and Regulation }\end{array}$ & 0.851852 & 2 \\
\hline 2 & $\begin{array}{l}\text { Higher investment cost } \\
\text { The lack of strategy that } \\
\text { promote sustainable } \\
\text { construction }\end{array}$ & 0.607407 & 4 \\
\hline 4 & $\begin{array}{l}\text { Lack of professional } \\
\text { knowledge }\end{array}$ & 0.77037 & 8 \\
\hline 5 & $\begin{array}{l}\text { Lack of Technology } \\
\text { Lack of Government } \\
\text { support }\end{array}$ & 0.696296 & 7 \\
\hline 6 & \multicolumn{1}{|l}{0.62963} & 9 \\
\hline
\end{tabular}




\begin{tabular}{|l|l|l|l|}
\hline 7 & Increased Documentation & 0.474074 & 10 \\
\hline 8 & Lack of Demand & 0.837037 & 3 \\
\hline 9 & Risk of investment & 0.859259 & 1 \\
\hline 10 & Lack of Expertise & 0.733333 & 6 \\
\hline
\end{tabular}

\section{CONCLUSION}

From the overall survey carried it can be concluded that the entire topic needs to be focused and for the same experts opinion and views for the same should be taken into consideration, and also use of sustainable materials should be increased and social awareness should be created. As per the technical aspect building byelaws and regulations are considered there should be more precise information compiling use of sustainable materials and procurement methods and also there should be good awareness among the top level to the bottom level personnel's along with the labors indulged in the project so as to reduce the construction risk which will help increase use of sustainable public procurement ways and methods thus helping the nature and the environment. As per the economic aspect in case of sustainable public procurement all the points can only be achieved when the customer is ready to pay high cost since sustainable materials are costlier than the traditional ones which are easily available locally and with which the workers work with greater efficiency. As per the environmental aspect use of lower hazardous material, Effective disposal of construction waste, protecting the natural environment are some of the points which are considered at the top most level. As per the social aspect social dignity can only be maintained if the company maintains and looks towards the interest of the people for whom they are doing the business. As per the probable reasons due to which sustainable procurement is not being practiced at high rate because of the risk of investment, the lack of building codes and regulation, lack of demand, the higher investment cost, and the lack of professional knowledge are the very important points which should be worked out very seriously by the industry increase use of sustainable public procurement. Now this can be achieved only if good awareness is created and there are strict rules and byelaws enforcing the use of such sustainable public procurement methods and materials, thus by helping to achieve the principle of sustainability in favor of the entire earth and human beings.

\section{REFERENCES}

[1]. Enock Gideon Musau; "Effects of Government Procurement on Prompt Tendering and Supply of Goods: A Case Study of Kenya Pipeline Company"; International Journal of Business and Management Invention, vol.4, No.1, January 2015, pp71-84.

[2]. Sylvia Chilikona Wanyonyi; "Factors Affecting Performance of Procurement Function among Public Technical Training Institutions in Kisumu County, Kenya"; International Journal of Economics, Commerce and Management, vol.3, No.5, May 2015, pp325-337.

[3]. Bo Xia, Qing Chen, Yelin Xu, Mei Li, Xiaohua Jin; "Design-Build Contractor Selection for Public
Sustainable Buildings"; Journal of Management in Engineering, March 2014, pp1-7.

[4]. Rajeev Ruparathna, S.M.ASCE, Kasun Hewage; "Review of Contemporary Construction Procurement Practices"; Journal of Management in Engineering, September 2014, pp1-11.

[5]. J. K. Yates, M.ASCE; "Design and Construction for Sustainable Industrial Construction"; Journal of Management in Engineering, June 2014, pp1-14.

[6]. Silas E. Njeru, Dr. Patrick Ngugi, Dr. Robert Arasa, Dr. James. Kahiri; "Procurement Policies and Implementation of Effective Procurement Practices in Tertiary Public Training Institutions in Kenya"; Global Advanced Research Journal of Management and Business Studies, Vol. 3, April 2014, pp166-170.

[7]. Brussels; "Communication from the Commission to the European Parliament, the council, the European Economic and Social committee and the committee of the regions on Resource Efficiency Opportunities in the Building Sector"; Study on Management of CDW in the EU, July 2014,pp1-10.

[8]. Duncan Brack; "Promoting Legal and Sustainable Timber: Using Public Procurement Policy";

[9]. Energy Environment and Resources, September 2014, pp1-23.

[10]. Gbadamosi Olaniyi Mufutau; "Practical Procurement Skill, Theory and Techniques"; Industrial Engineering Letters, vol.3, No.9, 2013, pp27-38.

[11]. Japheth Ocharo Kiage; "Factors Affecting Procurement Performance: A Case of Ministry of Energy"; International Journal of Business and Commerce, Vol. 3, No.1, Sept 2013, pp54-70.

[12]. Matthew Kalubanga; "SUSTAINABLE PROCUREMENT: Concept, and Practical Implications for the Procurement Process"; International Journal of Economics and Management Sciences, Vol.1, No.7, 2012, pp01-07.

[13]. Konstantinos I. Vatalis, Odysseus G. Manoliadis, Dimitrios G. Mavridis; "Project performance indicators as an innovative tool for identifying sustainability perspectives in green public procurement"; Procedia Economics and Finance, 2012, pp401 - 410 .

[14]. Peter E. D. Love, David J. Edwards, Zahir Irani, Amir Sharif; "Participatory Action Research Approach to Public Sector Procurement Selection"; Journal of Construction Engineering and Management, Vol. 138, No. 3, March 2012, pp311322.

[15]. Crina Oltean-Dumbrava, Greg Watts, Abdul Miah; "Procurement of Sustainable Noise-Reducing Devices: State-of-the-Art Review from EU Project QUIESST"; Journal of Management in Engineering, Vol. 28, No. 3, July 2012, pp324-329.

[16]. Dr. Anil Sharma, Dr. Anupama Sharma, N. K. Gupta; "Adoption of Green Building practices in Mass Housing Construction Projects LEED Rating"; International Journal of Advanced Engineering Technology, Vol.3,No.4,Oct.-Dec 2012,pp64-66. 
[17]. Lauren Bradley Robichaud, Vittal S. Anantatmula; "Greening Project Management Practices

[18]. for Sustainable Construction"Journal of Management in Engineering, Vol. 27, No. 1, January 2011,pp4857.

[19]. Dr. Robert Eadie,Ms. Clare McKeown,Mr. Ken Anderson; "The Social Element of Sustainable Civil Engineering Public Procurement in Northern Ireland"; International Journal of Business and Social Science, Vol. 2, No. 12, July 2011,pp36-42.

[20]. Cathy Berry, Shaun McCarthy; "Guide to sustainable procurement in construction"; CIRIA, 2011, pp1-25.

[21]. Kedar Uttam, Charlotta Faith-Ell, Berit Balfors; "Increasing IA effectiveness by green procurement"; International Conference Centre Geneva, April 2010, pp1-5.

[22]. Md Mahbubur Rahim; "Identifying Factors Affecting Acceptance of E-procurement Systems: An Initial Qualitative Study at an Australian City Council"; Communications of the IBIMA, vol 3, 2008, pp7-17.

[23]. Stephen Brammer, Helen Walker; "Sustainable procurement practice in the public sector: An international comparative study"; University of Bath School of Management Working Paper Series, 2007, pp1-36.

[24]. Delon Hampton, Fellow; "Procurement Issues"; Journal of Construction Engineering and Management, vol.10,No.6, Nov/Dec 1994,pp45-49.

[25]. Peter Boswell, Lorna Walker; "Procurement and process design"; FIDIC and Lorna Walker Consulting Ltd, pp1-18.

[26]. G OFORI; "Challenges of Construction Industries in Developing Countries: Lessons from Various Countries"; pp1-13.

[27]. John Karanja Ngugi, Hildah W. Mugo; "Internal Factors Affecting Procurement Process of Supplies in the Public Sector; A Survey of Kenya Government Ministries"; pp2314-2343.

[28]. Preparatory study Public Procurement needs and existing initiatives in Denmark, Jan 2011.

[29]. Green Tenders An Action Plan on Green Public Procurement.

[30]. Greening the building supply chain, 2014.

[31]. Final Business and Regulatory Impact Assessment; Public Contracts Scotland Progress Report, 2012.

[32]. André Martinuzzi, Robert Kudlak, Claus Faber, Adele Wiman; "CSR Activities and impacts of the construction sector"; pp1-28.

[33]. Public Procurement for Sustainable and Inclusive Growth

[34]. Sustainable Public Procurement Main streaming sustainability criteria in public procurement in developing countries, June 2012.

[35]. Capacity building for Sustainable public procurement, Jan 2009. Public Procurement as a tool for promoting more Sustainable Consumption and Production patterns, August 2008. 